\title{
NUTRITIONAL INFLUENCE ON THE ONSET OF RENAL DAMAGE DUE TO LONG-TERM ADMINISTRATION OF CADMIUM IN YOUNG AND ADULT RATS
}

\author{
Yasutoshi MuTo and Masahide OMORI ${ }^{1}$ \\ Department of Nutrition, School of Health Sciences, Faculty of Medicine, \\ University of Tokyo, Hongo, Tokyo, Japan
}

(Received January 21, 1977)

Summary This study was conducted to examine the effects of certain nutritional variables on the onset of renal damage due to oral administration of $\mathrm{Cd}$, and to investigate its reversibility by dietary switch-over in female rats during an observation period of 7 months.

Four dietary regimens were adopted: Two basal diets, including a multinutritionally deficient diet $(10 \%$ protein, $0.05 \% \mathrm{Ca}, 0.14 \% \mathrm{P}$ and no fiber) (designated L) and a normal balanced stock diet (designated $\mathrm{N}$ ); each diet was fed with and without the addition of $\mathrm{Cd} 200 \mathrm{ppm}$, and then the 4 diets were designated $\mathrm{L}(-), \mathrm{N}(-), \mathrm{L}(+)$ and $\mathrm{N}(+) .(+)$ indicates the addition of $\mathrm{Cd}$, while $(-)$ is without addition of $\mathrm{Cd}$. In comparison with the $\mathrm{N}(+)$ group, rats fed the $\mathrm{L}(+)$ diet for 7 months revealed the following distinct characteristics: 1) Marked growth retardation due mainly to decreases in food intake and food efficiency (Cdinduced protein-calorie malnutrition). 2) Marked depilation, general or localized, due to abnormal behavior of biting and eating each other's hair. 3) Progressive increase in $\mathrm{Cd}$ output in urine, particularly five months after starting the dietary treatment, and an increased output of urinary protein. 4) Significant elevation of accumulated $\mathrm{Cd}$ in the kidney (and also in the liver).

These observations were further supported by "switch-over" experiments, showing that the above-mentioned changes were reversed to normal when the $\mathrm{L}(+)$ diet was replaced by either the $\mathrm{L}(-)$ or even the $\mathrm{N}(+)$ diet, whereas the abnormal changes became evident when the diet was switched to the $\mathrm{L}(+)$ diet three months after the experiment. Moreover, renal accumulation of $\mathrm{Cd}$ was remarkably increased in the $\mathrm{L}(+)$ group, in spite of much less $\mathrm{Cd}$ intake than in the $\mathrm{N}(+)$ group.

These findings strongly suggest that nutritional factor(s) play an impor-

1 武藤泰敏, 大森正英 
tant role in the early development of $\mathrm{Cd}$ poisoning, in particular in the development of renal damage, presumably due to enhanced input of $\mathrm{Cd}$ in the body.

Chronic cadmium intoxication has been widely studied as one of the serious problems of environmental pollution ( 1 ). In fact, the Itai-itai (Ouch-ouch) disease found in limited areas of Japan was proposed to be a clinical syndrome of chronic entero-osteo-nephropathy due to $\mathrm{Cd}(2)$. The patients with this usually manifest renal damage and tubular proteinuria, and excrete a large amount of proteins of small molecular weight into the urine, including retinol-binding protein (RBP), which is one of the useful indicators for the early detection of tubular disorders(3-5).

In this laboratory (6), urinary excretion of RBP was successfully produced in large amounts in rabbit chronically poisoned with $\mathrm{Cd}$ (by parenteral injections). In contrast to parenteral administration of $\mathrm{Cd}$, urinary excretion of $\mathrm{RBP}$ was observed only when rats were fed a multi-nutritionally deficient diet with $\mathrm{Cd}$ for more than 7 months (7).

It has been suggested that in addition to long-term intake of Cd-contaminated water and rice, considerable reduction of dietary intakes of protein, fat and fatsoluble vitamins, as well as significantly less intake of $\mathrm{Ca}$, occurred in patients with Itai-itai disease during (or soon after) the World War II (see Ref. 1). Therefore, it is of considerable importance to explore further nutritional influences on the development of chronic $\mathrm{Cd}$ poisoning, although limited information is available on this problem $(8-11)$.

The present study was undertaken first to select a multi-nutritionally deficient diet in order to mimic the dietary conditions to which patients with Itai-itai disease were presumed to have been exposed, and to define more specifically nutritional influences on the early onset of renal damage due to oral alimentation of $\mathrm{Cd}$, and finally to assess its reversibility by dietary "switch-over". Studies on the relative contributions of specific dietary factors such as protein, calcium, phosphorus and fiber for renal accumulation of $\mathrm{Cd}$ will be reported in a related paper (12).

\section{METHODS}

Diet. The four diets used consisted of the two basal diets, $\mathrm{N}$ and $\mathrm{L}$ diet as indicated in Table 1, with and without the addition of $\mathrm{Cd}$ (designated $\mathrm{N}(+)$, $\mathrm{N}(-), \mathrm{L}(+)$ and $\mathrm{L}(-)$, respectively). Cadmium oxide (Koso Chemical Co., Ltd., Tokyo) was added to the basal diet in order to give a final concentration of Cd 200 ppm. $^{2}$ To prepare a homogeneous Cd-containing $\mathrm{L}(+)$ diet, it was of practical importance that a given amount of $\mathrm{CdO}$ be diluted in advance with some portion of casein, and then with successive additions of individual ingredients;

\footnotetext{
${ }^{2}$ On average, Cd content in the diet was found to be 189 ppm by atomic absorption spectro-
} photometric analysis. 
the $\mathrm{L}(+)$ diet looked faintly pinkish in color. In comparison with the $\mathrm{N}$ diet, the $\mathrm{L}$ diet was multi-nutritionally deficient, that is with low protein $(10 \%)$, low $\mathrm{Ca}$ $(0.05 \%)$, low $\mathrm{P}(0.14 \%)$ and no dietary fiber.

Table 1. Chemical compositions of two basal diets: $\mathrm{N}$ and $\mathrm{L}$ diet.

\begin{tabular}{lccc} 
& $\mathrm{N}$ diet $^{1}$ & \multicolumn{2}{c}{$\mathrm{L} \mathrm{diet}^{2}$} \\
\hline \multicolumn{1}{c}{ Ingredient } & \multicolumn{1}{c}{ Ingredient } & $\%$ \\
Carbohydrate & 57.0 & Cornstarch $^{3}$ & 78.0 \\
Protein & 26.6 & Milkcasein $^{4}$ & 10.0 \\
Fat & 4.9 & Soybean oil & 5.0 \\
Fiber & 4.3 & Fiber & - \\
Ash & 7.2 & Salt mixture & 5.5 \\
& & Vitamin mixture & 1.5 \\
\hline
\end{tabular}

1 Normal balanced stock diet, powdered (CE-2, Japan Clea Inc., Tokyo), in which Ca and $\mathrm{P}$ concentrations were determined to be 1.04 and $1.12 \%$ by atomic absorption spectrophotometric analysis and according to the method of CHEN et al. (13), respectively.

${ }^{2}$ Synthetic diet containing low protein, low $\mathrm{Ca}$ and $\mathrm{P}$ without fiber was specially prepared by Japan Clea Inc. The concentrations of $\mathrm{Ca}$ and $\mathrm{P}$ in the diet were also determined to be 0.05 and $0.14 \%$, respectively.

${ }^{3}$ Shono Starch Co., Mie-ken, Japan.

4 First grade, 80 mesh from Bay of Plenty Co-operative Dairy Co., Ltd., Jellicoe St., Te Puke, New Zealand.

5 Ajinomoto Co., Inc., Kawasaki City.

6 The following salts were made up to $5.5 \mathrm{~g}$ by adding lactose: $\mathrm{Ca}\left(\mathrm{H}_{2} \mathrm{PO}_{4}\right)_{2} \cdot \mathrm{H}_{2} \mathrm{O}, 250 \mathrm{mg}$; $\mathrm{NaCl}, 84.4 \mathrm{mg}$; $\mathrm{Na}_{2} \mathrm{CO}_{3}, 176 \mathrm{mg} ; \mathrm{K}_{2} \mathrm{CO}_{3}, 388 \mathrm{mg} ; \mathrm{MgCO}_{3}, 1,144 \mathrm{mg} ; \mathrm{ZnCO}_{3}, 4.2 \mathrm{mg}$; $\mathrm{FeSO}_{4} \cdot 7 \mathrm{H}_{2} \mathrm{O}, 13.6 \mathrm{mg} ; \mathrm{CuSO}_{4} \cdot 5 \mathrm{H}_{2} \mathrm{O}, 2.15 \mathrm{mg} ; \mathrm{MnSO}_{4} \cdot 7 \mathrm{H}_{2} \mathrm{O}, 16.9 \mathrm{mg}$, and $\mathrm{KI}, 40 \mu \mathrm{g}$.

7 The following vitamins were made up to $1.5 \mathrm{~g}$ by adding lactose: retinyl palmitate, $2.2 \mathrm{mg}$; vitamin $\mathrm{D}_{3}, 5 \mu \mathrm{g}$; $\alpha$-tocopherol, $11 \mathrm{mg}$; menadione, $4.95 \mathrm{mg}$; ascorbic acid, $100 \mathrm{mg}$; inositol, $11 \mathrm{mg}$; choline chloride, $165 \mathrm{mg}$; $p$-aminobenzoic acid, $11 \mathrm{mg}$; niacin, $10 \mathrm{mg}$; riboflavin, $2.2 \mathrm{mg}$; pyridoxine hydrochloride, $2.2 \mathrm{mg}$; thiamin hydrochloride, $2.2 \mathrm{mg}$; calcium pantothenate, $6.6 \mathrm{mg}$; folic acid, $0.2 \mathrm{mg}$; vitamin $\mathrm{B}_{12}, 3 \mu \mathrm{g}$ and biotin, $44 \mu \mathrm{g}$.

Animals. Young, female Wistar-strain rats (Japan Clea Inc., Tokyo), weighing about $110 \mathrm{~g}$, were maintained on the four different diets for an entire observation period of seven months, starting from June to December. Food and water were freely available. Fifty-one animals were initially divided into four groups; $\mathrm{N}(-) 8, \mathrm{~N}(+) 12, \mathrm{~L}(-) 12$ and $\mathrm{L}(+) 19$ rats, respectively. At the end of phase 1 (the first 3 months of the experiment), four rats in each group were sacrificed. The remainder in each group were either kept on the previous diet or fed a different diet ("switch-over" experiment) for the next four months (4 to 7 months of the experimental period; phase 2). Thirty-five rats, in fact, were distributed as follows: $\mathrm{N}(-) \rightarrow \mathrm{N}(-) 4, \mathrm{~N}(+) \rightarrow \mathrm{N}(+) 4, \mathrm{~N}(+) \rightarrow \mathrm{L}(+) 4, \mathrm{~L}(-) \rightarrow \mathrm{L}(-) 4, \mathrm{~L}(-) \rightarrow$ $\mathrm{L}(+) 4, \mathrm{~L}(+) \rightarrow \mathrm{L}(+) 7, \mathrm{~L}(+) \rightarrow \mathrm{N}(+) 4$, and $\mathrm{L}(+) \rightarrow \mathrm{L}(-)$ 4. Two rats in each of group $\mathrm{L}(+) \rightarrow \mathrm{L}(+)$ and $\mathrm{L}(+) \rightarrow \mathrm{L}(-)$ expired due to an accident.

Body weight was measured 3 times per week, and food intake estimated month- 
ly for a period of 3 days when each rat was housed in a metabolic cage (CT-10, Japan Clea Inc., Tokyo).

Urine was collected in a flask containing a few drops of $10 \%$ sodium azide (E. Merck, Darmstadt) for a period of two days, when individual rats were housed once a month in the metabolic cage. After recording the volume of urine collected, and centrifuging it at 2,000 $\mathrm{rpm}$ for $5 \mathrm{~min}$ at $2{ }^{\circ} \mathrm{C}, 10 \%$ sodium azide solution was added to adjust to a final concentration of $0.1 \%(\mathrm{w} / \mathrm{v})$ and the urine was stored frozen until analyzed.

At the end of the experiment, rats were killed by decapitation, and the kidneys and liver were immediately removed and stored at $-20^{\circ} \mathrm{C}$ until used.

Chemical analysis. Determination of $\mathrm{Cd}$ contents in the urine and the tissues (the kidneys and liver) was achieved by atomic absorption spectrophotometric analysis. Each sample was ashed with both sulfuric acid and hydrogen peroxide: the urine ( 2 to $20 \mathrm{ml}$ ) or tissues $(0.1$ to $0.2 \mathrm{~g}$ ) were initially heated with $5 \mathrm{ml}$ of $10 \mathrm{~N}$ $\mathrm{H}_{2} \mathrm{SO}_{4}$ on a hot plate fixed at $500^{\circ} \mathrm{C}$ for 1 to $3 \mathrm{hr}$. When a white vapor came up, several drops of concentrated $\mathrm{H}_{2} \mathrm{O}_{2}$ (JIS K 8230, Mitsubishi Gas Chemical Co., Tokyo) were added until the contents turned colorless, and the container was further heated until the white vapor re-appeared. After cooling, the whole content was quantitatively transfered into a volumetric flask, to which distilled water was added to give a final volume of $10.0 \mathrm{ml}$. The $\mathrm{Cd}$ concentration in the sample was measured with an atomic absorption and flame spectrophotometer (Shimadzu, model AA $610 \mathrm{~S}$ ) at a wavelength of 2288A. In addition, an internal standardization method was adopted for $\mathrm{Cd}$ determination in individual urine and tissues specimens using a standard solution of Cd (Wako Pure Chemical Industries, Ltd., Lot. 3-717). Overall recovery of Cd was found to be $99.2 \%$. Hence, the ashing method seems to be much less time-consuming and superior to the ordinary method of sulfuric acid-nitric acid digestion.

Urine protein concentration was assayed according to the method of PisCATOR (14).

\section{RESULTS}

\section{Changes of body weight (Fig. 1)}

Dietary influence on growth was markedly intensified by the addition of $200 \mathrm{ppm}$ Cd. Marked growth retardation in rats fed a multi-nutritionally deficient and Cd-added $\mathrm{L}(+)$ diet was observed as compared with that seen in rats fed a normal balanced and Cd-added $\mathrm{N}(+)$ diet. The rats maintained on the $\mathrm{L}(+)$ diet not only gained very little in the initial phase, but also steadily lost weight in a later phase. In addition, a distinct depilation on the head or back in these rats was observed as shown in Fig. 2, mainly due to abnormal behavior of biting each other's hair.

Immediate body weight gain was achieved when the $\mathrm{L}(+)$ diet was ex- 

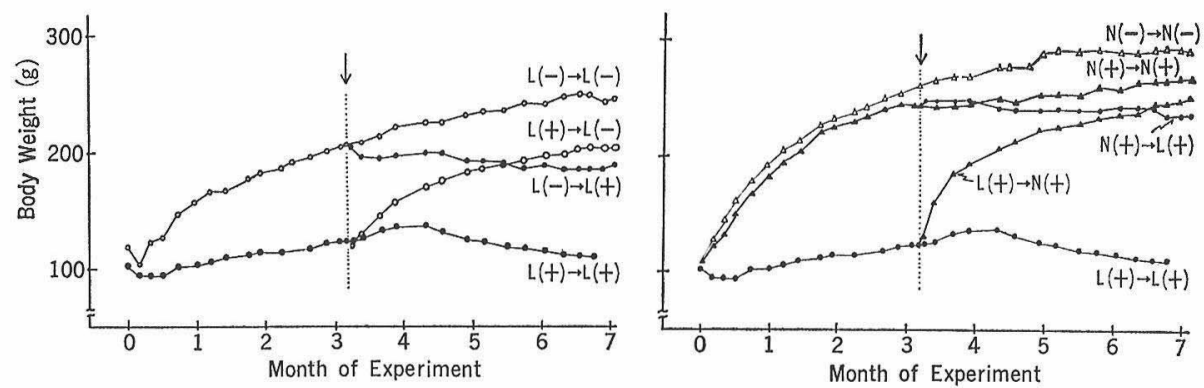

Fig. 1. Effects of the oral administration of cadmium on growth curves in rats fed either a multi-nutritionally deficient, $\mathrm{L}$ diet (the left panel) or a normal balanced, $\mathrm{N}$ diet (the right panel). Specific details on chemical compositions of the two diets are indicated in Table 1. (+) or (-); with or without addition of $200 \mathrm{ppm} \mathrm{Cd}$ in diet. Arrow indicates the point at which dietary switch-over was carried out as illustrated in the figure.

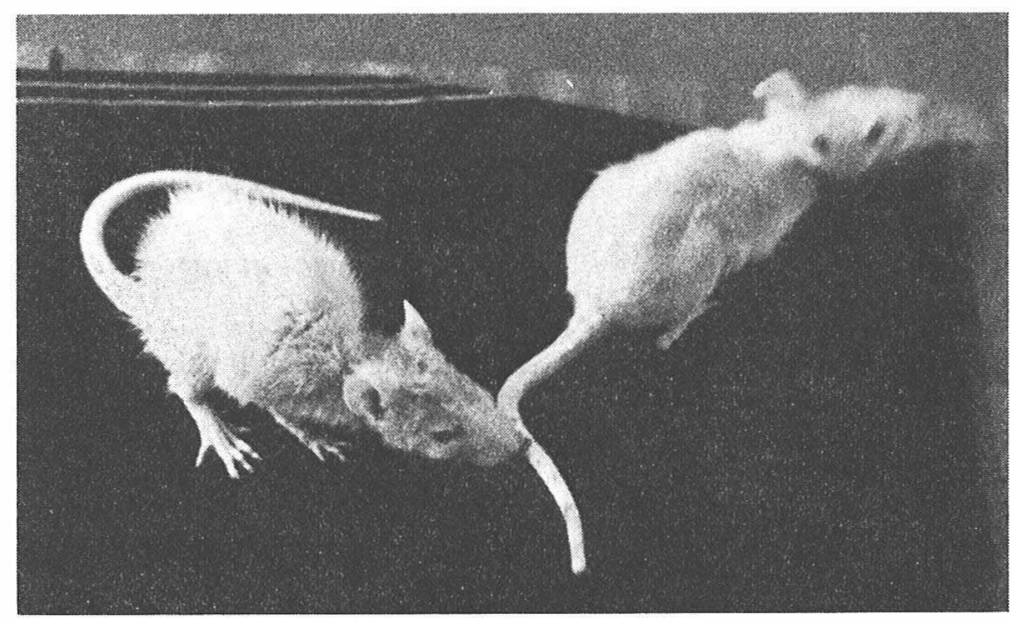

Fig. 2. Marked growth retardation with general or localized depilation (loss of hair on the head or back) in rats maintained on $\mathrm{L}(+)$ diet for seven months.

changed for either the $\mathrm{L}(-)$ or even the $\mathrm{N}(+)$ diet as shown in Fig. 1. On the other hand, significant decreases in body weight were brought about by switching of either the $\mathrm{L}(-)$ or $\mathrm{N}(+)$ diet to the $\mathrm{L}(+)$ diet. In addition to changes in body weight, the depilation of rat skin was also found to be reversible by switch-over of diets, although only the $\mathrm{N}$ diet was effective in complete regeneration of the hair. It is interesting that considerable amounts of the hair were found inside the gut (especially the colon) of rats fed the $\mathrm{L}(+)$ diet. However, no intra-intestinal hair was seen in the $\mathrm{N}(+)$ group, and far less intra-intestinal hair (about half) was seen in rats fed L (-) diet at the later phase of experiment, as compared with that 
of rats kept on $\mathrm{L}(+)$ diet.

The average daily food intake during both phase 1 and 2 (Table 2) was compatible with the changes in body weight seen in the respective experimental groups.

Table 2. Average daily food intake. ${ }^{1,2}$

\begin{tabular}{lc}
\hline Group & $\mathrm{g} /$ day \\
\hline Experimental period of 3 months (phase 1) & \\
$\mathrm{L}(-)$ & $11.3 \pm 1.0$ \\
$\mathrm{~L}(+)$ & $6.6 \pm 0.5^{* * * 3}$ \\
$\mathrm{~N}(-)$ & $13.2 \pm 0.5$ \\
$\mathrm{~N}(+)$ & $12.1 \pm 0.9$ \\
\hline
\end{tabular}

Experimental period between 4 and 7 months (phase 2)
$\mathrm{L}(-) \rightarrow \mathrm{L}(-)$
a)
$9.8 \pm 0.5$
a) $-b, d, e, g)^{* * * 4}$
$\mathrm{L}(-) \rightarrow \mathrm{L}(+)$
b)
$7.9 \pm 0.3$
a) $-\mathrm{f})^{* *}$
$\mathrm{L}(+) \rightarrow \mathrm{L}(-)$
c)
$9.6 \pm 0.3$
b) $-\mathrm{g}, \mathrm{h}$ ) $* * *$
b) - c)*
$\mathrm{L}(+) \rightarrow \mathrm{L}(+)$
d)
$6.9 \pm 0.6$
c) $-\mathrm{e})^{* * *}$
$\mathrm{L}(+) \rightarrow \mathrm{N}(+)$
e)
$\mathrm{N}(+) \rightarrow \mathrm{L}(+)$
$\mathrm{N}(+) \rightarrow \mathrm{N}(+)$
$\mathrm{N}(-) \rightarrow \mathrm{N}(-)$
h)
c) $-\mathrm{d}, \mathrm{f}, \mathrm{g})^{* *}$
d) $-\mathrm{g}, \mathrm{h})^{* * *}$
d) - e) $* *$
$11.4 \pm 0.6 \quad$ e) $-\mathrm{f})^{* * *}$
$8.2 \pm 0.5 \quad$ f) $-\mathrm{g}, \mathrm{h}$ ) $* * *$
$12.8 \pm 0.9$
g) - h) ${ }^{* * * *}$

${ }^{1}$ Food intake was measured monthly over a period of three days in individual rats, housed in metabolic cages, and then average daily food intakes were calculated at the two experimental phases (phase 1 and 2).

${ }^{2}$ Mean \pm SEM values are presented.

${ }^{3}$ Student's $t$-test analysis $(15)$ : $* * * * p<0.001 ; * * * p<0.01 ; * * p<0.02 ; * p<0.05$.

${ }^{4}$ Statistical comparisons (asterisks) refer to the groups as designated by the small alphabetical letters a) through $h$ ) (in the second column).

Food intake in rats fed the $\mathrm{L}(+)$ diet was found to be significantly less than those in other three groups at phase $1(p<0.01)$ and even phase $2(p<0.01)$. In the switch-over experiment in phase 2 , food intakes in $\mathrm{L}(+) \rightarrow \mathrm{N}(+)$ and $\mathrm{L}(+) \rightarrow$ $\mathrm{L}(-)$ group were significantly enhanced as compared with that in $\mathrm{L}(+) \rightarrow \mathrm{L}(+)$ group $(p<0.02)$, whereas $\mathrm{N}(+) \rightarrow \mathrm{L}(+)$ and $\mathrm{L}(-) \rightarrow \mathrm{L}(+)$ group exhibited significantly less food intake than the $\mathrm{N}(+) \rightarrow \mathrm{N}(+)$ group $(p<0.01)$.

Urinary excretion of $C d$ (Fig. 3)

Dietary influence on the urinary excretion of $\mathrm{Cd}$ was also observed. A marked increase in urinary output of $\mathrm{Cd}$ in the rats kept on $\mathrm{L}(+)$ diet was observed (final urinary $\mathrm{Cd}$ output, $12.9 \mu \mathrm{g} / \mathrm{day}$ ) five months after the treatment had begun, 
although these rats excreted a small amount of $\mathrm{Cd}$ into the urine even at the early stage. In contrast, rats maintained on $\mathrm{N}(+)$ diet showed only a slight increase in urinary output of $\mathrm{Cd}$ (about $2.1 \mu \mathrm{g} /$ day) even at the end of experiment.
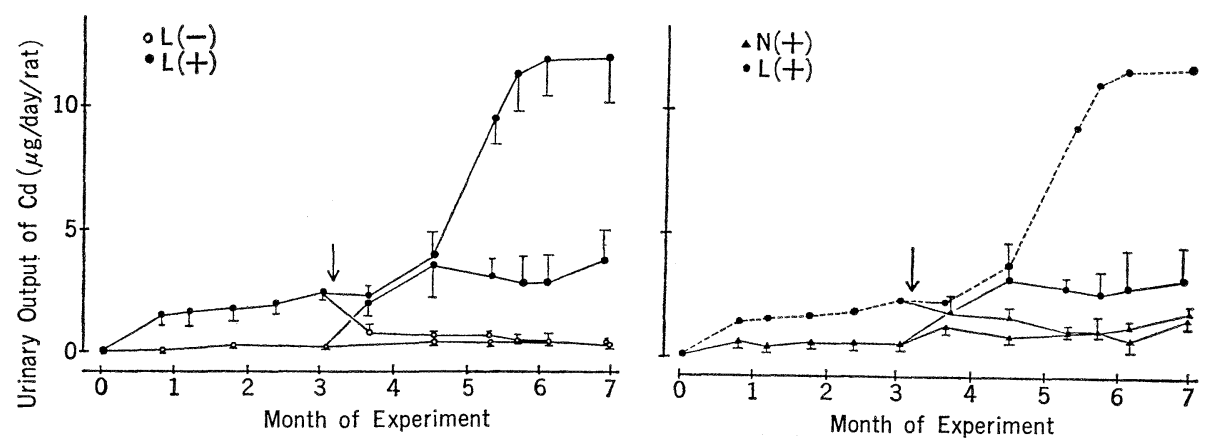

Fig. 3. Time course of changes in daily output of $\mathrm{Cd}$ in rat urine. Arrow indicates the point at which dietary switch-over was done. Closed and open circle are shown as the group fed $\mathrm{L}$ diet with and without $\mathrm{Cd}$, respectively. Closed triangle represents the group of rats fed $\mathrm{N}$ diet with $\mathrm{Cd}$. Mean $\pm \mathrm{SEM}$ values are indicated for rats in each of the dietary treatment groups.

In the switch-over experiment, this finding was further emphasized. Rats fed the $\mathrm{L}(+)$ diet in phase 2 , switched from either the $\mathrm{L}(-)$ or $\mathrm{N}(+)$ diet, excreted significantly more $\mathrm{Cd}$ into the urine than those kept on respective original diets. In contrast, immediate reduction of urinary $\mathrm{Cd}$ excretion was observed when the $\mathrm{L}(+)$ diet was replaced by either the $\mathrm{L}(-)$ or even the $\mathrm{N}(+)$ diet in phase 2 .

Urinary output of protein in rats maintained on the $\mathrm{L}(+)$ diet was increased at phase 2 (3 times elevated from 0.5 at the initial stage to $1.5 \mathrm{mg}$ protein/day at the end of experiment), despite large fluctuations of daily output of urinary protein.

Cadmium concentrations in the kidney and liver (Table 3)

At the end of phase 1 ( 3 months after the start of the experiment), marked increases in $\mathrm{Cd}$ concentrations of both kidney and liver were obtained in the $\mathrm{L}(+)$ group as compared with the $\mathrm{N}(+)$ group $(p<0.01)$. In each group, the kidney was found to contain more $\mathrm{Cd}$ than the liver.

At the end of phase 2 (the additional exposure to $\mathrm{Cd}$ for 4 months), Cd concentration of the kidney in rats kept on $\mathrm{L}(+)$ diet was found to be significantly higher than that in $\mathrm{N}(+) \rightarrow \mathrm{N}(+)$ group $(p<0.001)$, which level was also elevated as compared with that at phase 1 , but still lower than that found in $L(+)$ group at phase 1 . Of interest is the fact that remarkable elevation of kidney $\mathrm{Cd}$ was achieved when rats were fed the $\mathrm{L}(+)$ diet regardless of previous dietary conditions; i.e., either $\mathrm{L}(-)$ or $\mathrm{N}(+)$ diet at phase 1. In contrast, significant reduction of kidney $\mathrm{Cd}$ concentration was achieved when $\mathrm{L}(+)$ diet was switched to either $\mathrm{L}(-)$ 
or even $\mathrm{N}(+)$ diet $(p<0.02$ and $p<0.01$, respectively). Similar results were obtained with regard to changes in liver $\mathrm{Cd}$ concentration of rats under various dietary treatments.

Table 3. Cadmium concentrations in the kidney and liver. ${ }^{1}$

\begin{tabular}{ccc} 
Group & Kidney \\
& (micrograms per gram of wet weight) \\
\hline
\end{tabular}

\begin{tabular}{lcc} 
Phase 1: & 3 months after Cd exposure & \\
$\mathrm{L}(+)$ & $183.0 \pm 12.4^{* * * 2}$ & $137.1 \pm 10.9^{* * *}$ \\
$\mathrm{~N}(+)$ & $93.7 \pm 6.6$ & $53.5 \pm 4.8$ \\
\hline
\end{tabular}

Phase 2: 4 months after phase 1

\begin{tabular}{|c|c|c|c|c|c|}
\hline $\mathrm{L}(-) \rightarrow \mathrm{L}(+)$ & a) & $189.3 \pm 5.4$ & $\begin{array}{l}\text { a)-f) })^{* * * 3} \\
\text { a)-d)**** } \\
\text { a)-b)*** } \\
\text { a)-e)* }\end{array}$ & $154.6 \pm 7.3$ & $\begin{array}{l}\text { a) }- \text { f) } * * * \\
\text { a) }- \text { c) } * * \\
\text { a) }- \text { b) }\end{array}$ \\
\hline $\mathrm{L}(+) \rightarrow \mathrm{L}(-)$ & b) & $137.8 \pm 17.8$ & b) $-c)^{* *}$ & $118.5 \pm 1.5$ & $\begin{array}{l}\text { b) }- \text { c) } * * * \\
\text { b) }-f)^{*}\end{array}$ \\
\hline $\mathrm{L}(+) \rightarrow \mathrm{L}(+)$ & c) & $189.2 \pm 5.5$ & $\begin{array}{l}\text { c) }-\mathrm{f})^{* * * * *} \\
\text { c) }-\mathrm{d})^{* * * *}\end{array}$ & $187.7 \pm 6.8$ & $\begin{array}{l}\text { c) }- \text { f) } \\
\text { c) }- \text { d) } * * *\end{array}$ \\
\hline $\mathrm{L}(+) \rightarrow \mathrm{N}(+)$ & d) & $140.7 \pm 7.5$ & d)-e)* & $140.8 \pm 10.8$ & d) $-\mathrm{f}) * * *$ \\
\hline $\mathrm{N}(+) \rightarrow \mathrm{L}(+)$ & e) & $169.8 \pm 5.1$ & e)-f)*** & $152.0 \pm 12.8$ & e)-f)** \\
\hline $\mathrm{N}(+) \rightarrow \mathrm{N}(+)$ & f) & $121.7 \pm 2.8$ & & $92.0 \pm 5.0$ & \\
\hline
\end{tabular}

1 Mean \pm SEM values are presented.

${ }^{2}$ Student's $t$-test analysis: $* * * * p<0.001 ; * * * p<0.01 ; * * p<0.02 ; * p<0.05$.

${ }^{3}$ Statistical comparisons (asterisks) refer to the groups as designated by the small alphabetical letters a) through f) (in the second column).

\section{DISCUSSION}

The present study has clearly demonstrated that the extent of renal damage due to oral $\mathrm{Cd}$ administration is remarkably influenced by the nature of the diet, and has further verified the important role of dietary factor(s) in the early development of chronic $\mathrm{Cd}$ poisoning. Thus, the renal abnormalities were greatly intensified in young female rats when they were fed a diet multi-deficient in protein, calcium, phosphorus, and fiber, although the $\mathrm{Cd}$ content in the diet used was obviously very high.

The experimental conditions adopted in this study, such as the sex of the rat, route of $\mathrm{Cd}$ administration (per os and by diet), and the nutrients depleted were selected to more or less mimic the situation to which patients with Itai-itai disease had been exposed, as mentioned previously. Depletion of dietary fiber was also adopted in order to evaluate the intestinal role in $\mathrm{Cd}$ input, which will be mostly presented and discussed in a related paper (12). The switch-over of diets in the fourth month was selected for this study because the growth curve reached a plateau at that time shown in Fig. 1. 
The poor general condition observed in rats fed the multi-nutritionally deficient, Cd-added $\mathrm{L}(+)$ diet (marked growth retardation with general or localized depilation, hypoalbuminemia (analyzed by a Technicon Auto-Analyzer, SMA-12$60)$ and anemia) is assumed to represent a Cd-induced protein-calorie malnutritional state, although nitrogen balance was not determined. The severe growth retardation was mainly due to marked decreases in food intake (Table 2) and in food efficiency, which in the $\mathrm{L}(+)$ group was found to be $0.021 \mathrm{~g}$ body weight gain per $\mathrm{g}$ food intake, greatly lower than the $0.148 \mathrm{~g} / \mathrm{g}$ seen in the $\mathrm{N}(+)$ group at phase 1 . In other words, exogenous $\mathrm{Cd}$ appears not only to repress food intake (appetite), but also to be toxic for growth. As reported previously from this laboratory (6), parenteral administration of $\mathrm{Cd}$ to the rabbit brought about a marked reduction of body weight with tubular disorders (urinary excretion of RBP). Of interest is the fact that long-lasting excretion of urinary RBP without further reduction of body weight was achieved by $\mathrm{Cd}$ injections, mainly due to enhanced food intake, when the rabbit was given a tasteful saline solution in replacement of drinking water. The findings, in turn, strongly suggest that exogenous Cd itself, once it has reached the target organ, is toxic and responsible for the further development of tissue lesions independent of changes in body weight.

The remarkable depilation was found to be due to abnormal eating behavior (of hair), since regeneration of the hair was seen when a single rat was isolated from others, and because considerable amounts of the hair were found inside the colon. Hence, the abnormal change is not a spontaneous loss of the hair due to the malnutritional state (i.e., single deficiency of amino acid, etc.).

The major aim of this study was to evaluate differences in renal damage due to chronic Cd administration that would be seen under different dietary conditions. Renal damage was assessed by urinary excretion of Cd (Fig. 3) and renal accumulation of $\mathrm{Cd}$ (Table 3). A progressive increase in the urinary output of $\mathrm{Cd}$ in rats kept on the $\mathrm{L}(+)$ diet for seven months was found in conjunction with the highest level of $\mathrm{Cd}$ in the kidney. A histological study revealed an atrophic degeneration and desquamation of epithelial cells in the proximal tubulus of the kidney without distinct changes in the renal glomerulus (Murakami, M., Muto, Y., and Omori, M.; unpublished results). In addition, abnormal histological changes such as slight fibrosis along the portal area and proliferation of cholangioles were also observed in the liver of the $L(+) \rightarrow L(+)$ group, which was relevant to the marked elevation of serum transaminase activities (i.e., GOT 518 and GPT 167 i.u., respectively).

In contrast, no histological abnormalities in the kidney and liver of the $\mathrm{N}(+)$ $\rightarrow \mathrm{N}(+)$ group were observed, regardless of the slight increase in urinary excretion of $\mathrm{Cd}$ and elevated level of $\mathrm{Cd}(127 \mu \mathrm{g} / \mathrm{g})$ in the kidney. No distinct histological abnormalities were detected in any other experimental groups (both phase 1 and 2).

It is of considerable importance to compare relationships between accumulated levels of $\mathrm{Cd}$ in the kidney and total exposures to $\mathrm{Cd}$, as calculated from the food intakes, in individual groups at both phase 1 and 2, and summarized in Fig. 4. 

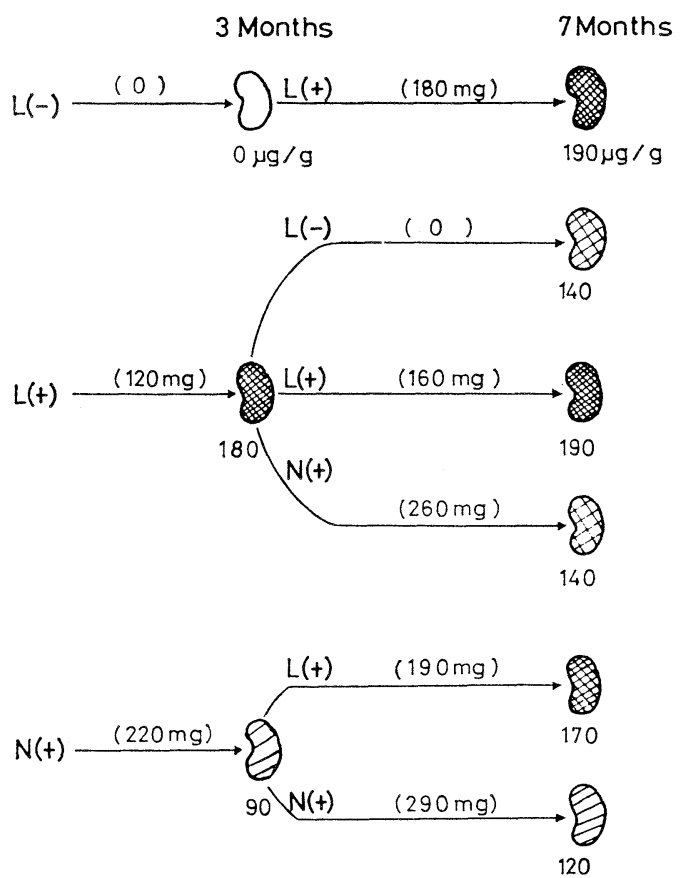

Fig. 4. Schematic illustration of the relationship between total exposure to Cd and accumulation of $\mathrm{Cd}$ in the kidney for experimental periods of 3 and 7 months. Parenthesis represents oral intake of $\mathrm{Cd}$ in milligrams.

At phase 1, the renal Cd level was found to be doubled in the $\mathrm{L}(+)$ group, despite an intake of about half as much total $\mathrm{Cd}$ as compared with the $\mathrm{N}(+)$ group. Regardless of previous dietary conditions, similar renal $\mathrm{Cd}$ levels were obtained when rats were fed $\mathrm{L}(+)$ diet during the four months of phase 2 . In general, it has been proposed that $\mathrm{Cd}$ accumulation in the kidney reaches a plateau of about $200 \mathrm{ppm}$, and the development of tissue lesion is determined by the integrated function of this critical $\mathrm{Cd}$ level and its duration (see Ref. 16). On the other hand, the $\mathrm{Cd}$ level in the $\mathrm{L}(+)$ group, such as $180 \mu \mathrm{g} / \mathrm{g}$ of kidney at phase 1 , was significantly lowered to about $140 \mu \mathrm{g} / \mathrm{g}$ in rats switched to either the $\mathrm{L}(-)$ or even $\mathrm{N}(+)$ diet at phase 2 (even though the $\mathrm{N}(+$ ) diet provided additional dietary $\mathrm{Cd}$ of $260 \mathrm{mg}$ in 4 months). These results strongly indicate that dietary factors play an important role in the accumulation of $\mathrm{Cd}$ in the kidney (and also the liver), presumably through mucosal or intestinal absorption and vascular transport of $\mathrm{Cd}$. In fact, disturbances in intestinal absorption of nutrients and histological abnormalities of the intestinal mucosa, such as atrophic degeneration of the epithelia similar to gluten-enteropathy, were observed in patients with Itai-itai disease as well as in experimental animals as reported by MurATA (2). In addition, it was also revealed in this study (at phase 2) that active transport of ${ }^{45} \mathrm{Ca}$ in the everted gut sac 
of $\mathrm{L}(+)$ or $\mathrm{N}(+)$ group rats was significantly decreased in comparison with that of $\mathrm{L}(-)$ or $\mathrm{N}(-)$ group rats $(p<0.02$ or $p<0.05)$, respectively (unpublished observations). Hence, nutritional influence on intestinal absorption of $\mathrm{Cd}$ and its biochemical consequences warrant further investigation.

In any event, the present study provides good evidence that nutritional factors play an important and crucial role in the early development of chronic $\mathrm{Cd}$ intoxication. Further exploration will be needed in order to define the effects of individual dietary factors, as examined to some extent in a related paper (12), and in order to improve our pathophysiological approaches to Itai-itai disease. Moreover,the finding is of practical importance to prevent occurrences of heavy metal poisoning in developing countries when rapid industrialization is introduced in the future.

The authors are grateful to Prof. N. Hosoya for his advice on the modification of the sulfuric acid-hydrogen peroxide digestion method for $\mathrm{Cd}$ analysis. We also would like to express our thanks to Dr. M. Kanai for blood chemical analyses by Auto-Analyzer, Dr. M. Murakami for histological examinations, and Dr. DeWitt S. Goodman for his very kind advice regarding the manuscript.

This work was supported in part by the Japan-US Cooperative Science Program, Grant 5R037 from the Japan Society for the Promotion of Science.

\section{REFERENCES}

1) Friberg, L., Piscator, M., Nordberg, G. F., and Kjellström, T. (1974): Health effects of cadmium in general environment in Japan. In Cadmium in the Environment, 2nd ed., CRC Press, Inc., Cleveland, pp. 137-161.

2) Murata, I. (1971): Chronic entero-osteo-nephropathy cadmium. J. Jap. Med. Assoc. (in Japanese), 65, 15-42.

3) Kanai, M., Nomoto, S., Sasaoka, S., and NaIKI, M. (1971): Clinical significance of urinary excretion of retinol-binding protein in patients with "Itai-Itai" disease. Proc. Symp. Chem. Physiol. Pathol., 11, 194-199.

4) Kanai, M., Nomoto, S., Sasaoka, S., and Muto, Y. (1972): Retinol-binding protein levels in blood and urine from patients with "Itai-Itai" disease: Pathological mechanism for its increased excretion. Proc. Symp. Chem. Physiol. Pathol., 12, 319-324.

5) KANAI, M., SASAOKA, S., and NAIKI, M. (1972): Radioimmunoassay of retinol-binding protein and its use for an early detection of renal tubular disorders and differentiation of proteinuric patterns. Proc. Symp. Chem. Physiol. Pathol., 12, 325-330.

6) Muto, Y., Nakanishi, M., and ShidoJI, Y. (1976): Urinary excretion of retinol-binding protein (RBP) in rabbit chronically poisoned with cadmium: Isolation and partial characterization of rabbit RBP. J. Biochem., 79, 775-785.

7) Muto, Y., SHidoJI, Y., and SuzukI, S. (1975): Effect of undernutrition on development of chronic cadmium poisoning in the rat. Nutrition \& Food (in Japanese), 28, 1-8.

8) Suzuki, S., Taguchi, T., and YoконаSHI, G. (1969): Dietary factors influencing upon the retention rate of orally administered ${ }^{11.5} \mathrm{~m} \mathrm{CdCl}_{2}$ in mice with special reference to calcium and protein concentrations in diet. Ind. Health, 7, 155-162.

9) Larsson, S. E. and Piscator, M. (1971): Effect of cadmium on skeletal tissue in normal and calcium deficient rats. Metabol. Bone Dis., 7, 495-498.

10) Itokawa, Y., ABE, T., and TANAKA, S. (1973): Bone changes in experimental chronic cad- 
mium poisoning. Arch. Environ. Health, 26, 241-244.

11) Itokawa, Y., Abe, T., Tabei, R., and Tanaka, S. (1974): Renal and skeletal lesions in experimental cadmium poisoning. Arch. Environ. Health, 28, 149-154.

12) OMORI, M., and Muto, Y. (1977): Effects of dietary protein, calcium, phosphorus and fiber on renal accumulation of exogenous cadmium in young rats. J. Nutr. Sci.Vitaminol., 23, 361-373.

13) Chen, P. S., Jr., Toribara, T. Y., and Warner, H. (1956): Microdetermination of phosphorus. Anal. Chem., 28, 1756-1758.

14) Piscator, M. (1962): Proteinuria in chronic cadmium poisoning. Arch. Environ. Health, 5, 325-332.

15) Steel, R. G. D. and Torrie, J. H. (1960): Principles and Procedures of Statistics. McGraw-Hill Book Co., New York.

16) Friberg, L., Piscator, M., Nordberg, G. F., and KJellström, T. (1974): Metabolism. In Cadmium in the Environment, 2nd. ed., CRC Press, Inc., Cleveland, pp. 23-91. 